\title{
The Relationship between Trait Emotional Intelligence and Self-efficacy among Iranian EFL Teachers
}

\author{
Jahanbakhsh Nikoopour \\ Islamic Azad University, North Tehran Branch, Iran \\ Mohammad Amini Farsani \\ Young Researchers Club, Islamic Azad University, North Tehran Branch, Iran \\ Email: mohammad_farsani@yahoo.com \\ Mohammad Tajbakhsh \\ Tarbiat Moallem University, Tehran, Iran \\ Seyedeh Hoda Sadat Kiyaie \\ Tarbiat Moallem University, Tehran, Iran
}

\begin{abstract}
The current study examined the relationship between Iranian EFL teachers' trait EI (trait EI) and Self-efficacy. To this end, 336 teachers were asked to complete "Trait Emotional Intelligence QuestionnaireShort Form (TEIQue-SF)" (Petrides and Furnham, 2006) and "Teacher Sense of Efficacy Scale (TSES)" (Tschannen-Moran \& Woolfolk Hoy, 2001). Pearson product-moment correlation showed a significant relationship between trait EI and self-efficacy. Trait EI subconstructs also showed significant relationship with Self-efficacy subconstructs as well as total self-efficacy. To investigate which subconstructs of trait emotional intelligence might have more predictive power in predicting teacher's self-efficacy, regression analysis was run. Results revealed all subconstructs of trait EI to be moderate predictors of Self-efficacy. In addition, the ANOVA were employed to investigate the influence of teachers' age, gender, and years of teaching experience on EI and Self-efficacy. Results showed teachers with more years of teaching experience to have achieved higher levels in both trait EI and self-efficacy. However no effect of EFL teachers' age, gender and their interactions on teachers' trait EI and Self-efficacy were observed.
\end{abstract}

Index Terms - trait emotional intelligence (trait EI), emotional intelligence, self-efficacy, Iranian EFL teachers

\section{INTRODUCTION}

Since its introduction in 1990 by Salovey and Mayer, Emotional intelligence (EI) has made such a strong heat in the last two decades which pushed aside many classical concepts of psychology. Proposing different theoretical models to describe EI, many scales to measure it and studies to investigate its relationship with other concepts and variables in various fields show the importance of EI in modern psychology (Fernández-Berrocal \& Extremera, 2006). Besides, since teachers dealing with human beings and their emotions have rarely been probed in terms of EI and its position in diverse aspects of teaching profession, a new trend of studies focused on EI and different aspects of teaching profession(Chan, 2004; Rastegar and Memarpour,2009; Moafian and Ghanizadeh 2009; Gürol, Özercan, and Yalçın ,2010). Herein, the current study investigates the relationship between teachers' trait EI and their Self-efficacy and the influence of their age, gender, and years of teaching experience on these two.

Trait Emotional intelligence (trait EI)

In the last century, the success and failure in life and career was believed to be mainly dependent on IQ which was believed to contain social and emotional aspects beside cognitive ones (Cantor \& Kihlstrom, 1987; Sternberg, 1985; Thorndike, 1920; Wechsler, 1943). However in the last two decades, after its first introduction by Salovey \& Mayer (1990) and thanks to Emotional Intelligence (Goleman, 1995), many mainly in the lay, believed another concept; emotional intelligence (EI), to be the most important determiner of success and failure. Whether IQ or EI is considered as the main determiner of success and failure, the new concept of EI has proved to be a legitimate area in new psychology (Fernández-Berrocal \& Extremera, 2006) in such a way that different theoretical models to its investigation have been proposed and used in different studies during the last two decades.

The origins of emotional intelligence (EI), goes back to Thorndike's (1920) idea of 'social intelligence' and Gardner's (1983) 'intrapersonal' and 'interpersonal' intelligences. EI could be divided into two main trends based on the measurement method used in operationalization, ability EI and trait EI (Petrides et al., 2000, 2001, 2003). Ability EI is defined as "the ability to perceive accurately, appraise and express emotion; the ability to access and/or generate 
feelings when they facilitate thought; the ability to understand emotion and emotional knowledge; and the ability to regulate emotions to promote emotional and intellectual growth" (Mayer and Salovey,1997,p. 10). Ability EI is viewed as a cognitive ability and operationalized via maximal performance IQ-like tests, however it has proven problematic (Brody, 2004) mainly due to objectification of an inherently subjective construct in a way similar to IQ (Robinson \& Clore, 2002). There are other models which are to a great extend based on EI ability model by Mayer et, al. (1997). BarOn's Emotional-Social Intelligence (ESI) model (Bar-On, 1997) which uses "competence", "skill" to refer to a self perceived concept through a self report questionnaire, and the emotional competencies model focused on the workplace (Goleman, 1998, 2001) with an unclear background and terminology. Beside the above theoretical model and measurement instruments of EI there exist other measurement devices and scales such as Emotional Intelligence Scale (EIS) (Schutte, Malouff, Hall, Haggerty, Cooper, Golden, \& Dornheim, 1998) which are based on the above models and inherit their measurement and psychometric drawbacks( Brody, 2004; Freudenthaler \& Neubauer, 2005, 2007).

The most newly developed model of EI is trait EI (Petrides et al., 2001) which is defined as "a constellation of emotional self-perceptions located at the lower levels of personality hierarchies and measured via the trait emotional intelligence questionnaire (Petrides, Pita, \& Kokkinaki, 2007). During its short life, trait EI proved the following advantages ; recognizing subjectivity of emotional experience (Robinson \& Clore, 2002), integrating the construct of EI into mainstream theories of differential psychology (e.g. Petrides, Frederickson, \& Furnham, 2004; Mavroveli, Petrides, Rieffe, \& Bakker, 2007; Petrides, Sangareau, Furnham, \& Frederickson, 2006;Villanueva \& Sanchez, 2007; Sevdalis, Petrides, \& Harvey, 2007; Dewaele, Petrides, Furnham, 2008; Smith, Heaven, \& Ciarrochi,2008; Johnson, Batey,\&Holdsworth, 2009; Quoidbach \& Hansenne,2009;), potentials to interpret data from other questionnaires of EI and extending to original area of its development(Petrides, 2010).

Trait Emotional Intelligence Questionnaire-Short Form (TEIQue-SF) (Petrides et al., 2006) measuring trait EI is the EI measurement device based on Trait Emotional Intelligence Questionnaire-long form (Petrides, 2001) containing 153 items in 15 facets distributed in four subconstructs; wellbeing(Self-esteem, Trait happiness, Trait optimism), self control ( Impulsiveness(low), Stress management, Emotion regulation), emotionality( Emotion expression, Relationship skills, Trait empathy, Emotion perception (self and others)), sociability( Assertiveness, Emotion management, Social competence) beside global trait EI( Self-motivation, Adaptability). Cooper \& Petrides, 2010 showed TEIQue to have better psychometric properties in comparison to other EI measurement scales.

\section{Teacher self-efficacy}

The concept of self-efficacy rooted in the social cognitive theory is defined by Bandura (1986) as "the belief in one's capabilities to organize and execute the courses of action required managing prospective situations".

Bandura (2006) believed peoples' perceptions of environmental opportunities and impediments; choice of activities, amount of efforts expended on an activity and duration of perseverance confronting obstacles (Pajares, 2002) is determined by their efficacy beliefs.

In educational context, teacher efficacy has been defined as "a teacher's judgment of his or her capabilities to bring about desired outcomes of student engagement and learning, even among those students who may be difficult or unmotivated" (Bandura, 1977; Tschannen- Moran, Woolfolk Hoy, \& Hoy, 1998; Tschannen-Moran et al., 2001, p. 783) which may have a positive or negative effect on teachers' attitudes and behaviors (Tschannen-Moran et al., 1998; Henson, Stephens \& Grant 1999; Palmer, 2006).

Many researchers showed teacher self-efficacy to be an essential subconstruct in improving teacher education (e.g., Scharmann \& Hampton, 1995; Ross, 1998; Goddard, Hoy, \& Woolfolk Hoy, 2000; Tschannen-Moran et al., 2001), while having association with their students' academic achievements (Armor, Conroy-Oseguera, Cox, King, McDonnell, Pascal, Pauly, \& Zellman,1976; Gibson \& Dembo,1984; Anderson, Greene, \& Loewen, 1988; Ross, 1992,1998; Bandura,1993; Goddard, et al., 2000; Chambers and Hardy, 2005), motivation (Midgley, Feldlaufer, \& Eccles, 1989), and their own sense of efficacy (Anderson et al., 1988), as well as to different teacher classroom behaviors influencing the teacher's attempt in teaching, and his or her resilience to deal with difficult students (Gibson et al., 1984; Ashton \& Webb, 1986; Meijer \& Foster, 1988; Soodak \& Podell, 1993). Good and Brophy (2003) also stated teachers with higher levels of self-efficacy perception maintained higher levels of student participation.

Although many studies on EI have been done during the last two decades (Fernández-Berrocal and Extremera, 2006), a few of them have dealt with interrelationship between EI and Self-efficacy especially in foreign language learning situations. Regarding the interrelation between EI and Self-efficacy; Chan (2004) found significant relationship between EI and perceived Self-efficacy using EIS (Schutte et al., 1998) and Schwarzer (1993) respectively. Using EIS and TSES Rastegar and Memarpour (2009); Gürol, Özercan, and Yalçın (2010) found a positive significant correlation between perceived EI and self-efficacy of English teachers and pre-service teachers respectively; however, no significant differences among teachers with different genders, ages and teaching experiences were reported.

In another study Moafian and Ghanizadeh (2009) studied 89 Iranian EFL teachers using TSES and "Bar-On EI test" (1997), which showed a significant relationship between the teachers' emotional intelligence and their self-efficacy. Three subscales of emotional intelligence were found to be good predictors of teacher self-efficacy.

Various studies focused on investigating EI (Mayer et al., 1997; Bar-On, 1997; Goleman, 2001), while each one assessed this construct from a separate perspective. Due to the drawbacks of such studies Brody (2004), Cooper et al., (2010) considered trait EI which is more operationalized than the previous ones. The rationale behind using trait EI in 
this study was its privileges as a more reliable and valid research instrument. Regarding teachers Self-efficacy, TSES proved to be one of the most reliable and widely used research instruments (e.g. Klassen, Bong, Usher, Chong, Huan, Wong, \& Georgiou, 2009; Tschannen-Moran et al., 2001).

\section{METHOD}

\section{Participants}

The participants of this study were 336 EFL teachers teaching at different language institutes in Tehran who were selected based on the availability and consent of institutes' officials. There were 102 male and 228 female teachers from different socioeconomic background (Table 1). Their ages and years of teaching experiences range from 19 to 60 $(\mathrm{M}=28.60, \mathrm{SD}=6.86)$ and $1-27$ years $(\mathrm{M}=6.04, \mathrm{SD}=4.99)$ respectively.

\section{Instruments}

Trait Emotional Intelligence Questionnaire-Short Form (TEIQue-SF): Trait Emotional Intelligence QuestionnaireShort Form (Petrides et al., 2006) contains 30 items in 7-point Likert scale ranging from 1(completely disagree) to 7(completely agree). It's based on Trait Emotional Intelligence Questionnaire-long form (Petrides, 2001) containing 153 items in 15 facets due to four subconstructs; wellbeing, self control, emotionality, sociability beside global trait EI. Cooper et al., 2010 showed TEIQue to have better psychometric properties in comparison to other EI measurement scales. The Cronbach's alpha for the Persian version of TEIQue-SF was .85.The second instrument, Teacher Sense of Efficacy Scale (TSES) long -form (Tschannen-Moran et al., 2001) as one of the most widely used scales of teachers self-efficacy contains 24 items in 9-point Likert scale ranging from 1(nothing) to 9(a great deal). TSES long-form comprises three subscales: Efficacy in Student Engagement, Efficacy in Instructional Strategies, and Efficacy in Classroom Management. Persian versions of the TSES long-form showed high reliabilities of $\alpha=.89$.

\section{Procedure}

Participants were given 30 minutes to answer the items in the questionnaires while researchers provided needed help and instructions. Each questionnaire helped the researchers to elicit three types of information, namely, factual, attitudinal, and behavioral. Before participants take part in the study, the researchers convinced them to express their ideas honestly and ensured them that the information would be used for research purposes only.

\section{DATA ANALYSIS AND RESUlts}

\section{Participants' Information}

Tables 2, 3 present the descriptive statistics about participants age, and years of teaching experience.

TABLE 1.

DESCRIPTIVE INFORMATION ABOUT GENDER OF THE PARTICIPANTS.

\begin{tabular}{|llll|}
\hline & & Frequency & Percent \\
\hline Valid & male & 102 & 30.4 \\
& female & 228 & 67.9 \\
\cline { 2 - 4 } & Total & 330 & 98.2 \\
\hline
\end{tabular}

TABLE 2.

DESCRIPTIVE INFORMATION ABOUT AGE OF THE PARTICIPANTS.

\begin{tabular}{|llll|}
\hline & & Frequency & Percent \\
\hline Valid & 25 AND BELOW & 118 & 35.1 \\
& 26 TO 30 & 143 & 42.6 \\
& 31 and above & 75 & 22.3 \\
\cline { 2 - 4 } & Total & 336 & 100.0 \\
\hline
\end{tabular}

TABLE 3.

DESCRIPTIVE INFORMATION ABOUT YEARS OF TEACHING EXPERIENCE OF THE PARTICIPANTS.

\begin{tabular}{|llll|}
\hline & Frequency & Percent \\
\hline Valid & 1 to 3 & 94 & 28.0 \\
& 4 to 7 & 98 & 29.2 \\
& 8 and above & 71 & 21.1 \\
\cline { 2 - 4 } & Total & 263 & 78.3 \\
\hline
\end{tabular}

The relationship between trait EI and its subconstructs with self-efficacy and its subconstructs

Using SPSS, Pearson Product-Moment Correlation Coefficient was run to explore the relationship between teachers' trait EI and their Self-efficacy. The results showed a significant correlation $(r=0.54 ; \mathrm{p}<0.05)$ between teachers trait EI and their Self-efficacy (Table 5).

Table 4 indicates the descriptive statistics of the participants' total trait EI $(\mathrm{M}=111.97)$ and total self-efficacy (M= 86.61). As it is clear in Table 5,a Pearson product-moment correlation was employed o explore the relationship between 
teachers' trait EI and their self-efficacy which revealed a significant positive correlation between total trait EI and total Self-efficacy $(r=0.54, \mathrm{p}<0.05)$.

TABLE 4.

DESCRIPTIVE STATISTICS OF TRAIT EI AND SELF-EFFICACY.

\begin{tabular}{|llllll|}
\hline & $\mathrm{N}$ & Min & Max & Mean & SD \\
\hline Total Trait EI & 336 & 72.00 & 150.00 & 111.97 & 14.06198 \\
Total self-efficacy & 336 & 52.00 & 120.00 & 86.61 & 10.97565 \\
\hline
\end{tabular}

TABLE 5.

CORRELATION BETWEEN TEACHERS' TRAIT EI AND SELF-EFFICACY

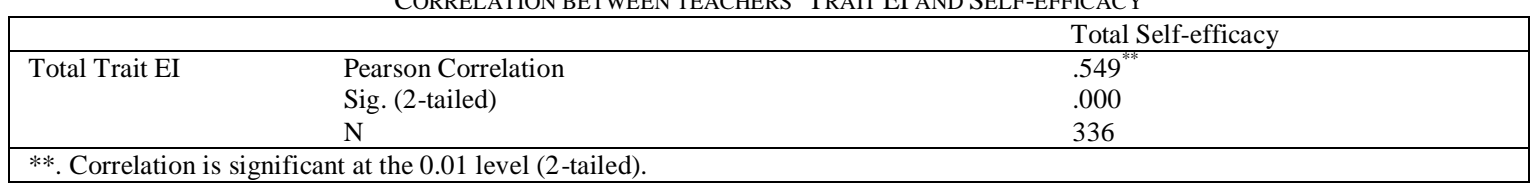

Table 6 shows moderate to strong correlation between EFL Iranian teachers Trait EI subconstructs and self-efficacy subconstructs. Well being shows the highest correlation with Efficacy in Classroom Management $(r=0.39)$, Self control with Efficacy in Classroom Management $(r=0.37)$, Sociality with Efficacy in Student Engagement $(r=0.34)$, Emotionality with Efficacy in Instructional Strategies $(r=0.34)$, and Global Trait EI with Efficacy in Classroom Management $(r=0.34)$. However, Self control shows the lowest correlation with Efficacy in Student Engagement $(r=$ 0.22) ( $\mathrm{p}<0.05)$. Moreover, Trait EI subconstructs' moderate to strong correlation with total Self-efficacy is presented in table 7. Well beings correlation with self- efficacy is $(r=0.42)$, self control with self- efficacy $(r=0.39)$, sociality with self- efficacy $(r=0.40)$, emotionality with self-efficacy $(r=0.40)$, and global trait EI with self- efficacy $(r=0.38)$ $(\mathrm{p}<0.05)$.

TABLE 6.

CORRELATION BETWEEN TEACHERS' TRAIT EI SUBCONSTRUCTS AND SELF-EFFICACY SUBCONSTRUCTS

\begin{tabular}{|c|c|c|c|c|}
\hline & & EIS & ESE & ECM \\
\hline Well Being & $\begin{array}{l}\text { Pearson Correlation } \\
\text { Sig. (2-tailed) } \\
\text { N }\end{array}$ & $\begin{array}{l}.307^{* *} \\
.000 \\
336\end{array}$ & $\begin{array}{l}.357^{* *} \\
.000 \\
336\end{array}$ & $\begin{array}{l}.396^{* *} \\
.000 \\
336\end{array}$ \\
\hline Self Control & $\begin{array}{l}\text { Pearson Correlation } \\
\text { Sig. (2-tailed) } \\
\text { N }\end{array}$ & $\begin{array}{l}.331^{* *} \\
.000 \\
336\end{array}$ & $\begin{array}{l}.227^{* *} \\
.000 \\
336\end{array}$ & $\begin{array}{l}.373^{* * *} \\
.000 \\
336\end{array}$ \\
\hline Sociability & $\begin{array}{l}\text { Pearson Correlation } \\
\text { Sig. (2-tailed) } \\
\mathrm{N}\end{array}$ & $\begin{array}{l}.315^{* *} \\
.000 \\
336\end{array}$ & $\begin{array}{l}.349^{* *} \\
.000 \\
336\end{array}$ & $\begin{array}{l}.326^{* *} \\
.000 \\
336\end{array}$ \\
\hline Emotionality & $\begin{array}{l}\text { Pearson Correlation } \\
\text { Sig. (2-tailed) } \\
\text { N }\end{array}$ & $\begin{array}{l}.344^{* *} \\
.000 \\
336\end{array}$ & $\begin{array}{l}.325^{* *} \\
.000 \\
336\end{array}$ & $\begin{array}{l}.313^{* *} \\
.000 \\
336\end{array}$ \\
\hline Global Trait EI & $\begin{array}{l}\text { Pearson Correlation } \\
\text { Sig. (2-tailed) } \\
\text { N }\end{array}$ & $\begin{array}{l}.305^{* *} \\
.000 \\
336\end{array}$ & $\begin{array}{l}.335^{* *} \\
.000 \\
336\end{array}$ & $\begin{array}{l}.341^{* *} \\
.000 \\
336\end{array}$ \\
\hline
\end{tabular}

TABLE 7.

CORRELATION BETWEEN TEACHERS' TRAIT EI SUBCONSTRUCTS AND TOTAL SELF-EFFICACY

\begin{tabular}{|l|ll|}
\hline \multicolumn{2}{|l|}{} & \multicolumn{1}{|c|}{ Self-efficacy } \\
\hline Well Being & Pearson Correlation & $.421^{* *}$ \\
& Sig. (2-tailed) & .000 \\
& $\mathrm{~N}$ & 336 \\
\hline Self Control & Pearson Correlation & $.391^{* *}$ \\
& Sig. (2-tailed) & .000 \\
& $\mathrm{~N}$ & 336 \\
\hline Sociability & Pearson Correlation & $.403^{* *}$ \\
& Sig. (2-tailed) & .000 \\
\hline Emotionality & $\mathrm{N}$ & 336 \\
\hline & Pearson Correlation & $.409^{* *}$ \\
& Sig. (2-tailed) & .000 \\
& $\mathrm{~N}$ & 336 \\
\hline Global Trait EI & Pearson Correlation & $.389^{* *}$ \\
& Sig. (2-tailed) & .000 \\
& $\mathrm{~N}$ & 336 \\
\hline **. Correlation is significant at the 0.01 level (2-tailed). & \\
\hline
\end{tabular}


A regression analysis was also run to investigate each of trait EI subconstructs' predictive power in predicting teachers' Self-efficacy (Table 9).

Model summery statistics, Table 8 shows the R value of 0.55 for multiple correlation coefficients between teachers' self-efficacy and the components of the trait EI. Its square value is 0.30 which means that the independent variable, trait EI, can predict and explain for 30\% of variation in the dependent variable, teachers' Self-efficacy. Table 9 shows the result of regression analysis for trait EI and Self-efficacy. All subconstructs of trait EI are positive predictors of Selfefficacy with weak to moderate predictive power.

The Beta value is a measure of how strongly each predicator (independent) variable influences the criterion (dependent) variable. The Beta is measured in units of standard deviations. For example, a Beta value of 0.145 indicates that a change of one standard deviation in well being will result in a change of 0.145 standard deviations in the teachers Self-efficacy. Thus, the higher the Beta value, the greater the impact of the predictor variable on the criterion variable. In table 9, sociality as a subconstructs of trait EI has the most impact on the teachers' Self-efficacy $(\beta=0.197)$

TABLE 8.

$\mathrm{R}^{2}$ TABLE FOR TRAIT EI AS THE PREDICTOR OF TEACHERS' SELF-EFFICACY

\begin{tabular}{|lllll|}
\hline Model & $\mathrm{R}$ & $\mathrm{R}^{2}$ & Adjusted $\mathrm{R}^{2}$ & SD \\
\hline 1 & $.555^{\mathrm{a}}$ & .308 & .298 & 9.19585 \\
\hline a. Predictors: (Constant), global trait EI, sociability, self control, emotionality, wellbeing & \\
\hline
\end{tabular}

TABLE 9.

REGRESSION ANALYSIS FOR TEACHERS’ TRAIT EI AND THEIR SELF-EFFICACY.

\begin{tabular}{|c|c|c|c|c|c|c|}
\hline \multirow{2}{*}{\multicolumn{2}{|c|}{ Model }} & \multirow{2}{*}{$\begin{array}{l}\text { Unstandardized } \\
\text { B }\end{array}$} & \multirow{2}{*}{$\frac{\text { Coefficients }}{\text { Std. Error }}$} & \multirow{2}{*}{$\begin{array}{l}\text { Standardized Coefficients } \\
\text { Beta }\end{array}$} & \multirow[t]{2}{*}{$\mathrm{t}$} & \multirow[t]{2}{*}{ Sig. } \\
\hline & & & & & & \\
\hline 1 & (Constant) & 37.982 & 4.061 & & 9.354 & .000 \\
\hline & Well Being & .386 & .156 & .145 & 2.470 & .014 \\
\hline & Self Control & .429 & .165 & .142 & 2.593 & .010 \\
\hline & Emotionality & .431 & .166 & .144 & 2.594 & .010 \\
\hline & Sociality & .587 & .158 & .197 & 3.719 & .000 \\
\hline & Global Trait EI & .342 & .139 & .137 & 2.465 & .014 \\
\hline
\end{tabular}

Differences in trait EI and self-efficacy according to gender, age, and years of teaching experience

To investigate possible effect of gender, age, years of experience and their interactions on Iranian teachers' trait EI and Self-efficacy, three way ANOVA with trait EI and Self-efficacy as dependent variables was run.

The ANOVA analysis showed a strong effect of teaching experience on teachers trait $\mathrm{EI}\left(\mathrm{F}_{(2,243)}=4.62, \mathrm{p}<0.05\right.$, $\eta^{2}=0.037$ )(Table 10), as teachers with $1-3$ years of teaching experience have the lowest levels of trait EI $(\mathrm{M}=107.76$, $\mathrm{SD}=2.08)$; teachers of 4-7 years of teaching experience take the next level in trait $\mathrm{EI}(\mathrm{M}=113.98, \mathrm{SD}=1.77)$ and those with 8 and above years of teaching experience have the highest level of trait EI $(M=118.08, S D=3.03)$ (Table 11). A Scheffe Post-hoc test revealed that teachers with1-3 years of teaching experience and teachers of 4-7 years of teaching experience are very similar in terms of emotional intelligent ( $p>0.05$ ). However, teachers of 1-3 and 4-7 years of teaching experience and teachers found to be significantly less emotionally intelligent than teachers of 8 and above years of teaching experience $(\mathrm{p}<0.05)$. (Table 12)

Moreover, no strong effect for gender $\left(\mathrm{F}_{(1,243)}=1.78, \mathrm{p}=0.18>0.05, \eta^{2}=0.007\right)$; age $\left(\mathrm{F}_{(2,243)}=1.05, \mathrm{p}=0.35>0.05\right.$, $\left.\eta^{2}=0.009\right)$; gender and age interaction $\left(\mathrm{F}_{(2,243)}=0.58, \mathrm{p}=0.55>0.05, \eta^{2}=0.005\right)$; gender and years of teaching experience and teachers interaction $\left(\mathrm{F}_{(2,243)}=1.02, \mathrm{p}=0.35>0.05, \eta^{2}=0.008\right)$; age and years of teaching experience and teachers interaction $\left(\mathrm{F}_{(4,243)}=0.17, \mathrm{p}=0.95>0.05, \eta^{2}=0.003\right)$; and gender, age and years of teaching experience and teachers interaction $\left(\mathrm{F}_{(4,243)}=0.44, \mathrm{p}=0.77>0.05, \eta^{2}=0.007\right)$ were observed. $($ Table 10$)$ 
TABLE 10.

ANOVA ANALYSIS- TRAIT EI AND YEARS OF TEACHING EXPERIENCE

\begin{tabular}{|c|c|c|c|c|c|}
\hline \multicolumn{6}{|l|}{ Tests of Between-Subjects Effects } \\
\hline \multicolumn{6}{|l|}{ Dependent Variable: trait EI } \\
\hline Source & $\begin{array}{l}\text { Type III Sum of } \\
\text { Squares }\end{array}$ & df & Mean Square & $\mathrm{F}$ & Sig. \\
\hline GENDER & 327.356 & 1 & 327.356 & 1.786 & .183 \\
\hline AGE & 386.839 & 2 & 193.420 & 1.055 & .350 \\
\hline YEXP & 1693.775 & 2 & 846.887 & 4.621 & .011 \\
\hline GENDER * AGE & 215.997 & 2 & 107.999 & .589 & .556 \\
\hline GENDER * years of teaching experience & 377.284 & 2 & 188.642 & 1.029 & .359 \\
\hline AGE $*$ years of teaching experience & 128.591 & 4 & 32.148 & .175 & .951 \\
\hline $\begin{array}{l}\text { GENDER * AGE * years of teaching } \\
\text { experience }\end{array}$ & 327.356 & 4 & 81.839 & .447 & .775 \\
\hline Error & 44537.441 & 243 & 183.282 & & \\
\hline Total & 3389545.000 & 261 & & & \\
\hline
\end{tabular}

TABLE 11.

DESCRIPTIVE STATISTICS OF YEARS OF TEACHING EXPERIENCE FOR TRAIT EI

\begin{tabular}{|llllll|}
\hline & & & & \multicolumn{2}{c|}{$95 \%$ Confidence Interval } \\
\cline { 3 - 6 } Years of teaching experience & $\mathrm{N}$ & Mean & Std. Error & Lower Bound & Upper Bound \\
\hline to 3 & 94 & 107.762 & 2.083 & 103.660 & 111.865 \\
4 to 7 & 98 & 113.982 & 1.777 & 110.481 & 117.483 \\
8 and above & 71 & 118.080 & 3.039 & 112.095 & 124.066 \\
\hline
\end{tabular}

TABLE 12.

MULTIPLE COMPARISONS FOR TRAIT EI

\begin{tabular}{|c|c|c|c|c|c|c|}
\hline \multirow{2}{*}{$\begin{array}{l}\text { (I) years of } \\
\text { teaching } \\
\text { experience }\end{array}$} & \multirow{2}{*}{$\begin{array}{l}(\mathrm{J}) \text { years of teaching } \\
\text { experience }\end{array}$} & \multirow[b]{2}{*}{ Mean Difference (I-J) } & \multirow[b]{2}{*}{ Std. Error } & \multirow[b]{2}{*}{ Sig. } & \multicolumn{2}{|c|}{$95 \%$ Confidence Interval } \\
\hline & & & & & Lower Bound & Upper Bound \\
\hline \multirow[t]{2}{*}{1 to 3} & 4 to 7 & -4.7644 & 1.96476 & .055 & -9.6035 & .0746 \\
\hline & 8 and above & $-10.5376^{*}$ & 2.13359 & .000 & -15.7925 & -5.2828 \\
\hline 4 to 7 & 8 and above & $-5.7732^{*}$ & 2.11446 & .025 & -10.9809 & -.5655 \\
\hline
\end{tabular}

*. The mean difference is significant at the 0.05 level.

The ANOVA analysis also revealed a strong effect of teaching experience on teachers Self-efficacy $\left(\mathrm{F}_{(2,243)}=7.17\right.$, $\mathrm{p}<0.05, \eta^{2}=0.056$ )(Table 13), as teachers with8 and above years of teaching experience and teachers have the highest level of Self-efficacy $(M=94.48, S D=2.2)$ fallowed by teachers of 4-7 years of teaching experience and teachers $(\mathrm{M}=87.67, \mathrm{SD}=1.28)$ and next teachers with 1-3 years of teaching experience and teachers $(\mathrm{M}=84.37, \mathrm{SD}=1.5)(\mathrm{Table}$ 14). A Scheffe Post-hoc test revealed that teachers with1-3 years of teaching experience and teachers to be significantly less emotionally intelligent than teachers of 4-7 years of teaching experience and teachers who themselves found to be significantly less emotionally intelligent than teachers of 8 and above years of teaching experience and teachers $(\mathrm{ps}<0.05)$. (Table 15)

Moreover, no strong effect for gender $\left(\mathrm{F}_{(1,243)}=0.71, \mathrm{p}=0.398>0.05, \eta^{2}=0.003\right)$; age $\left(\mathrm{F}_{(2,243)}=0.02, \mathrm{p}=0.97>0.05\right.$, $\left.\eta^{2}=0.000\right)$; gender and age interaction $\left(\mathrm{F}_{(2,243)}=0.7, \mathrm{p}=0.55>0.05, \eta^{2}=0.003\right)$; gender and years of teaching experience and teachers interaction $\left(\mathrm{F}_{(2,243)}=1.16, \mathrm{p}=0.31>0.05, \eta^{2}=0.009\right)$; age and years of teaching experience and teachers interaction $\left(\mathrm{F}_{(4,243)}=0.47, \mathrm{p}=0.95>0.05, \eta^{2}=0.014\right)$; and gender, age and years of teaching experience and teachers interaction $\left(\mathrm{F}_{(4,243)}=1.12, \mathrm{p}=0.31>0.05, \eta^{2}=0.019\right)$ were observed. $($ Table 13$)$ 
TABLE 13.

ANOVA ANALYSIS- SELF-EFFICACY AND YEARS OF TEACHING EXPERIENCE

\begin{tabular}{|c|c|c|c|c|c|}
\hline \multicolumn{6}{|l|}{ Tests of Between-Subjects Effects } \\
\hline \multicolumn{6}{|l|}{ Dependent Variable: Self-efficacy } \\
\hline Source & $\begin{array}{l}\text { Type III Sum of } \\
\text { Squares }\end{array}$ & df & Mean Square & $\mathrm{F}$ & Sig. \\
\hline GENDER & 69.080 & 1 & 69.080 & .718 & .398 \\
\hline years of teaching experience & 1380.911 & 2 & 690.456 & 7.178 & .001 \\
\hline AGE & 5.105 & 2 & 2.552 & .027 & .974 \\
\hline GENDER $*$ years of teaching experience & 223.244 & 2 & 111.622 & 1.160 & .315 \\
\hline GENDER * AGE & 66.460 & 2 & 33.230 & .345 & .708 \\
\hline years of teaching experience $*$ AGE & 342.905 & 4 & 85.726 & .891 & .470 \\
\hline $\begin{array}{l}\text { GENDER * years of teaching experience * } \\
\text { AGE }\end{array}$ & 455.899 & 4 & 113.975 & 1.185 & .318 \\
\hline Error & 23373.945 & 243 & 96.189 & & \\
\hline Total & 2050555.000 & 261 & & & \\
\hline
\end{tabular}

TABLE 14.

DESCRIPTIVE STATISTICS OF YEARS OF TEACHING EXPERIENCE FOR SELF-EFFICACY

\begin{tabular}{|llllll|}
\hline & & & & \multicolumn{2}{l|}{$95 \%$ Confidence Interval } \\
\cline { 4 - 6 } Years of teaching experience & $\mathrm{N}$ & Mean & Std. Error & Lower Bound & Upper Bound \\
\hline 1 to 3 & 94 & 84.375 & 1.509 & 81.402 & 87.347 \\
4 to 7 & 98 & 87.674 & 1.288 & 85.138 & 90.210 \\
8 and above & 71 & 94.486 & 2.201 & 90.150 & 98.822 \\
\hline
\end{tabular}

TABLE 15.

MULTIPLE COMPARISONS FOR SELF-EFFICACY

\begin{tabular}{|llcccc|}
\hline $\begin{array}{l}\text { (I) years of } \\
\text { teaching } \\
\text { experience }\end{array}$ & $\begin{array}{l}\text { (J) years of teaching } \\
\text { experience }\end{array}$ & Mean Difference (I-J) & Std. Error & Sig. & \multicolumn{2}{c|}{\begin{tabular}{c} 
L5\% Confidence Interval \\
\cline { 2 - 6 } 1 to 3
\end{tabular}} & 4 to 7 & $-4.7201^{*}$ & 1.42335 & .005 & -8.2257 \\
& 8 and above & $-9.9976^{*}$ & 1.54566 & .000 & -13.8044 \\
4 to 7 & 8 and above & $-5.2775^{*}$ & 1.53180 & .003 & -9.0502 \\
\hline
\end{tabular}

*. The mean difference is significant at the 0.05 level.

\section{DisCUSSION}

The current study aims to investigate the relationship between Iranian EFL teachers' trait EI and their Self-efficacy in English language programs. Nonetheless, it supports the literature in the sense that there is a significant positive correlation between teachers' trait EI and their Self-efficacy (Chan, 2004; Rastegar et al., 2009; Moafian et al., 2009; Gürol et al., 2010). Also, trait EI subconstructs show significant positive correlation with self- efficacy and Selfefficacy subconstructs which may be due to moderating role of trait EI's underlying facets.

There was no difference in terms of trait EI among teachers of different different gender and age. These findings support previous studies' results such as Chan, 2004; Rastegar et al., 2009; Moafian et al., 2009; Gürol et al., 2010 which found no significant difference between teachers' EI and their age and gender. However, while contrasting with previous studies, results revealed strong relationship between teachers' trait EI with different years of teaching experience. As more experienced teachers were found to be more emotionally intelligent.

Regarding teachers' gender, age, years of teaching experiences, and their interrelationship effects on Self-efficacy, no effect were observed but for years of teaching experience. In line with previous studies (Chan, 2004; Rastegar et al., 2009; Moafian et al., 2009; Gürol et al., 2010) male and female teachers of different ages were very similar in terms of their Self-efficacy. Moreover, in contradiction of previous studies, teachers with different years of teaching experience were found to be different in terms of their perceived self-efficacy as more experienced teachers were more self efficacious.

It can be claimed that the ability to recognize and handle emotions has direct relationship with higher sense of efficacy which would have powerful effects on teachers' control orientations and control behaviors; their use of classroom discussions and innovative teaching practices; their responses to learners who are difficult to teach; their levels of stress and their satisfaction with the teaching profession (Tschannen-Moran, Woolfolk Hoy, \& Hoy, 1998). Perched at lower levels of personality hierarchies and similar to them, trait EI necessitates matching individual's profiles to specific jobs which need individuals with specific profile and characteristics. This helps teacher education programs by choosing candidates with higher levels in trait EI which may directly lead to their higher levels of selfefficacy in classrooms. 
Due to the positive correlation between the two main constructs in general and their subconstructs in particular, it might be interpreted that these two main variables have much in common. Therefore, the trait EI as the predictor variable can influence the teachers Self-efficacy which is a very important factor in improving teachers' professional behavior. Pedagogically speaking, teachers' Self-efficacy can be improved while the condition for its enhancement is provided. This could be explained since teaching mainly deals with learners and their emotions, teaching experience may moderate teachers' EI and Self-efficacy through improving their understanding of learners' needs and emotions. Such aspects which might help develop teachers' Self-efficacy and emotional intelligence are to be investigated and analyzed meticulously to see what they are exactly, what their mechanisms are, what sorts of interactions or interrelationships they have in order to be transferred to novice teachers to improve their professional behaviors. In further replications, other factors such as teachers' motivation, personality type, career orientation, sense of plausibility, teaching style, thinking style, etc. are recommended to be studied.

Among trait EI subconstructs well being showed the most significant correlation with total Self-efficacy and Efficacy in Classroom Management. This could be explained due to underlying facets of well being, self-esteem, trait happiness and trait optimism, which make teachers perceive their self- efficacy more optimistically. This signifies how teachers' having a positive view toward their job and life could increase their achievements in class. Global trait EI made the lowest correlation among trait EI subconstructs with total Self-efficacy and Efficacy in Instructional Strategies which may be due to situation in Iranian language institutes' dictated by institutes officials which make teachers to follow them.

Teachers' trait EI is not so simple to be assessed by the available research tools. It is a complicated, multifaceted variable for which some more replications are required. Therefore, when the interaction between this variable with another complex trait, that is, teachers' Self-efficacy is of investigation, more cautions should be taken into account. Teachers, especially in EFL situations in which learning is intermingled with emotions, can improve their trait EI and consequently their Self-efficacy through seeking help from more experienced teachers.

\section{REFERENCES}

[1] Anderson, R., Greene, M., \& Loewen, P. (1988). Relationships among teachers' and students' thinking skills, sense of efficacy, and student achievement. Alberta Journal of Education Research, 34, 148-165.

[2] Armor, D., Conroy-Oseguera, P., Cox, M., King, N., McDonnell,L., Pascal, A., Pauly, E., \& Zellman, G. (1976). Analysis of the school preferred reading program in selected Los Angeles minority schools. Report No. R-2007-LAUSD; ERIC Document Reproduction No. 130 243. Santa Monica, CA: Rand Corporation.

[3] Ashton, P. T., \&Webb, R. B. (1986). Making a difference: Teachers' sense of efficacy and student achievement. New York: Longman.

[4] Bar-On, R., 1997. The Emotional Quotient Inventory (EQ-I): Technical Manual. Multi-Health Systems, Toronto.

[5] Bandura, A. (1977). Self-efficacy: Toward a unifying theory of behavioral change. Psychological Review, 84, 191-215.

[6] Bandura, A. (1986). Social foundations of thought and action: A social cognitive theory. Englewood Cliffs, NJ: Prentice-Hall.

[7] Bandura, A. (1993). Perceived self-efficacy in cognitive development and functioning. Educational Psychologist, 28, 117-148.

[8] Bandura, A. (2006). Adolescent development from an agentic perspective. In F. Pajares, \& T. Urdan (Eds.), Self-efficacy beliefs of adolescents (pp. 1-43). Greenwich, Connecticut: Information Age Publishing.

[9] Brody, N. (2004). What cognitive intelligence is and what emotional intelligence is not. Psychological Inquiry, 15, $234-238$.

[10] Cantor, N., \& Kihlstrom, J. (1987). Personality and social intelligence. Englewood Cliffs, NJ: Prentice Hall.

[11] Chambers S., M. \& Hardy J., C. (2005). Length of time in student teaching: Effects on Classroom Control Orientation and SelfEfficacy Beliefs. Educational Research Quarterly, 28(3), 3-9.

[12] Chan, D.W., 2004. Perceived emotional intelligence and self-efficacy among Chinese secondary school teachers in Hong Kong. Personality and Individual Differences 36 (8), 1781-1795.

[13] Cooper, A. \& Petrides, K. V. (2010). A psychometric analysis of the Trait Emotional Intelligence Questionnaire-Short Form (TEIQue-SF) using Item Response Theory. Journal of Personality Assessment, 92, 449-457.

[14] Dewaele, J-M., Petrides, K. V., Furnham, A. (2008). Effects of Trait Emotional Intelligence and Sociobiographical Variables on Communicative Anxiety and Foreign Language Anxiety Among Adult Multilinguals: A Review and Empirical Investigation. Language Learning 58:4, 911-960.

[15] Fernández-Berrocal, P., \& Extremera, N.(2006).Emotional intelligence: A theoretical and empirical review of its first 15 years of history. Psicothema 2006. Vol. 18, supl., pp. 7-12

[16] Freudenthaler, H. H., \& Neubauer, A. C. (2005). Emotional intelligence: The convergent and discriminant validities of intraand interpersonal emotional abilities. Personality and Individual Differences, 39, 569-579.

[17] Freudenthaler, H. H., \& Neubauer, A. C. (2007). Measuring emotional management abilities: Further evidence of the importance to distinguish between typical and maximum performance. Personality and Individual Differences, 42, 1561-1572.

[18] Gardner, H. (1983). Frames of mind: The theory of multiple intelligences. New York: Basic Books.

[19] Gibson, S., \& Dembo, M. (1984). Teacher efficacy: a construct validation. Journal of Educational Psychology, 76, 569-582.

[20] Goddard, R. D., Hoy, W. K., \& Woolfolk, A. (2000). Collective teacher efficacy: its meaning, measure, and effect on student achievement. American Education Research Journal, 37, 479-507.

[21] Goleman, D. (1995). Emotional intelligence. New York: Bantam.

[22] Goleman, D. (1998). Working with emotional intelligence. New York: Bantam Books.

[23] Goleman, D. (2001). Emotional intelligence: perspectives on a theory of performance. In C. Cherniss \& D. Goleman (eds.): The emotionally intelligent workplace. San Francisco: Jossey-Bass.

[24] Good, T. L., \& Brophy, J. E. (2003). Looking in classrooms (9th e-d.). Boston: Allyn and Bacon. 
[25] Gürol. A, Özercan, M. G., Yalçın, H. (2010). A comparative analysis of pre-service teachers' perceptions of Self-efficacy and emotional intelligence. Procedia Social and Behavioral Sciences, 2, 3246-3251

[26] Henson, R., K., Stephens, J. \& Grant, G., S. 1999. Self-efficacy in preservice teachers. Annual Meeting of the Southwest Educational Research Association. 21-23 January 1999. San Antonio.

[27] Johnson, S. J., Batey, M., \& Holdsworth, L. (2009). Personality and health: The mediating role of trait emotional intelligence and work locus of control. Personality and Individual Differences, 47, 470-475.

[28] Klassen, R.M., Bong, M., Usher, E.L., Chong, W.H., Huan, V.S., Wong, I.Y.F. \& Georgiou, T. (2009). Exploring the validity of a teachers' self-efficacy scale in five countries. Contemporary Educational Psychology, 34(1)pp, 67-76

[29] Mavroveli, S., Petrides, K. V., Rieffe, C., \& Bakker, F. (2007). Trait emotional intelligence, psychological well-being, and peer-rated social competence in adolescence. British Journal of Developmental Psychology, 25, 263-275.

[30] Mayer, J.D. \& Salovey, P. (1997). What is emotional intelligence? In P.Salovey \& D. Sluyter (eds.): Emotional development and emotional intelligence: educational applications (pp. 3-31). New York: Basic Books.

[31] Meijer, C. J. W., \& Foster, S. F. (1988). The effect of teacher self-efficacy on referral change. Journal of Special Education, 22 378-385.

[32] Midgley, C., Feldlaufer, H., \& Eccles, J. S. (1989). Change in teacher efficacy and student self- and task-related beliefs in mathematics during the transition to junior high school. Journal of educational Psychology, 81, 247-258.

[33] Moafian, F \& Ghanizadeh, A. (2009). The relationship between Iranian EFL teachers' emotional intelligence and their selfefficacy in Language Institutes. System, $37,708-718$

[34] Pajares, F. (2002). Overview of social cognitive theory and of self-efficacy. Retrieved June 15, 2004, from http://www.emory.edu/EDUCATION/mfp/eff.html.

[35] Palmer, D. 2006. Durability of changes in self-efficacy of preservice primary teachers. International Journal of Science Education. 28(6), 655-671.

[36] Petrides, K. V. (2001). A psychometric investigation into the construct of emotional intelligence. Unpublished doctoral dissertation, University College London.

[37] Petrides, K. V. (2010). Trait Emotional Intelligence Theory. Industrial and Organizational Psychology, 3, 136-139.

[38] Petrides, K. V., Frederickson, N., \& Furnham, A. (2004). The role of trait emotional intelligence in academic performance and deviant behaviour at school. Personality and Individual Differences, 36, 277-293.

[39] Petrides, K. V., \& Furnham, A. (2000). On the dimensional structure of emotional intelligence. Personality and Individual Differences, 29, 313-320.

[40] Petrides, K. V., \& Furnham, A. (2001). Trait emotional intelligence: Psychometric investigation with reference to established trait taxonomies. European Journal of Personality, 15, 425-448.

[41] Petrides, K.V., \& Furnham, A. (2003). Trait emotional intelligence: Behavioural validation in two studies of emotion recognition and reactivity to mood induction. European Journal of Personality, 17, 39-57.

[42] Petrides, K. V. \& Furnham, A. (2006). The role of trait emotional intelligence in a gender-specific model of organizational variables. Journal of Applied Social Psychology, 36, 552-569.

[43] Petrides, K. V., Pita, R., \& Kokkinaki, F. (2007). The location of trait emotional intelligence in personality factor space. British Journal of Psychology, 98,273-289.

[44] Petrides, K. V., Sangareau, Y., Furnham, A., \& Frederickson, N. (2006). Trait emotional intelligence and children's peer relations at school. Social Development, 15, 537-547.

[45] Quoidbach, J., \& Hansenne, M. (2009). The impact of trait emotional intelligence on nursing team performance and cohesiveness. Journal of Professional Nursing , 25, 23-29.

[46] Rastegar, M. \& Memarpour, S. (2009). The relationship between emotional intelligence and self-efficacy among Iranian EFL teachers. System, 37, 700-707

[47] Robinson , M. D., \& Clore, G. L. (2002). Belief and feeling: Evidence for an accessibility model of emotional self-report. Psychological Bulletin, 128, 934-960.

[48] Ross, J. A. (1992). Teacher efficacy and the effect of coaching on student achievement. Canadian Journal of Education, 17, 51-65.

[49] Ross, J. A. (1998). The antecedents and consequences of teacher efficacy. In J. Brophy (Ed.), Advances in research on teaching, Vol. 7 (pp. 49-73). Greenwich, CT: JAI Press.

[50] Salovey, P. \& Mayer, J.D. (1990). Emotional intelligence. Imagination, Cognition and Personality, 9, 185-211

[51] Scharmann , L. C., \& Hampton, C. M. O. (1995). Cooperative learning and preservice elementary teacher science selfefficacy. Journal of Science Teacher Education, 6(3), 125-133.

[52] Schutte, N. S., Malouff, J. M., Hall, L. E., Haggerty, D. J., Cooper, J. T., Golden, C. J., \& Dornheim, L. (1998). Development and validation of a measure of emotional intelligence. Personality and Individual Differences, 25, 167-177.

[53] Schwarzer, R. (1993). Measurement of perceived self-efficacy. Psychometric scales for cross-cultural research. Berlin, Germany: Freie Universität Berlin.

[54] Sevdalis, N., Petrides, K. V., \& Harvey, N. (2007). Trait emotional intelligence and decision-related emotions. Personality and Individual Differences, 42, 1347-1358.

[55] Smith, L., Heaven, P. C. L., \& Ciarrochi, J. (2008). Trait emotional intelligence, conflict communication patterns, and relationship satisfaction. Personality and Individual Differences, 44, 1314-1325.

[56] Soodak, L. C., \& Podell, D. M. (1993). Teacher efficacy: Toward the understanding of multi-faceted construct. Teaching and Teacher Education, 12, 401-411.

[57] Soodak, L. C., \& Podell, D. M. (1996). Teacher efficacy: Toward the understanding of a multi-faceted construct. Teaching and Teacher Education, 12, 401-412.

[58] Sternberg, R. J. (1985). Beyond IQ. A triarchic theory of human intelligence. location: Cambridge University Press.

[59] Thorndike, R. L. (1920). Intelligence and its uses. Harper's Magazine, 140, 227-235.

[60] Tschannen-Moran, M., Woolfolk Hoy, A., Hoy, W.K., 1998. Teacher efficacy: its meaning and measure. Review of 
Educational Research 68 (2), 202-248.

[61] Tschannen-Moran, M., \& Woolfolk Hoy, A. (2001). Teacher efficacy: Capturing an elusive construct. Teaching and Teacher Education, 17, 783-805.

[62] Villanueva, J. J., \& Sanchez, J. C. (2007). Trait emotional intelligence and leadership self-efficacy: Their relationship with collective efficacy. Spanish Journal of Psychology, 10, 349-357.

[63] Wechsler, D. (1943). Non-intellective factors in general intelligence. Journal of Abnormal and Social Psychology, 38, 101-103.

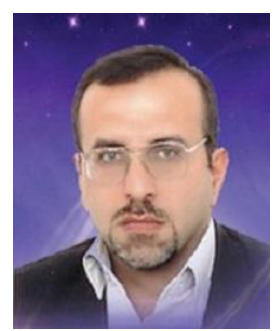

Jahanbakhsh Nikoopour is an assistant professor in TEFL (Teaching English as a Foreign Language) at Islamic Azad University, Tehran North Branch, Tehran, Iran .His research interests include language assessment, factors influencing language learning, CALL, reading in a foreign language, and material development. He has published articles on a variety of domestic and international academic journals and has presented some papers in both international and domestic conferences.

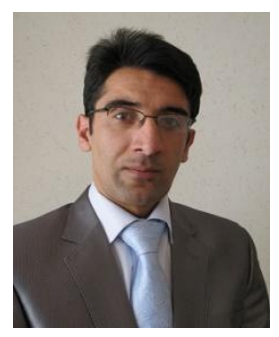

Mohammad Amini Farsani is an MA student in TEFL (Teaching English as a Foreign Language) at Tarbiat Moallem University, Tehran, Iran .He is also a member of Young Researchers Club at Islamic Azad University, Tehran North Branch. His research interests include language assessment, factors influencing language learning, CALL, reading in a foreign language, and material development. He has published articles on a variety of domestic and international academic journals and has presented some papers in both international and domestic conferences.

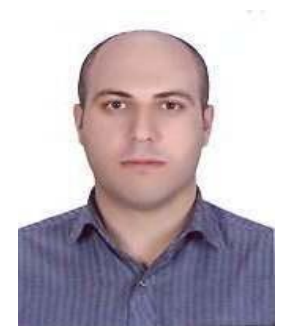

Mohammad Tajbakhsh has received his associate degree in TEFL from Shahid Mofateh Teacher Training Center and has been teaching English in schools and Interchange series since 2005, Tehran, Iran. He achieved a bachelor in TEFL from Shahid Rajaee Teacher Training University. He is currently a master's student at Tarbiat Moallem University, Tehran, Iran. His professional interests are emotional intelligence, learners' styles and strategies, and teacher's characteristics.

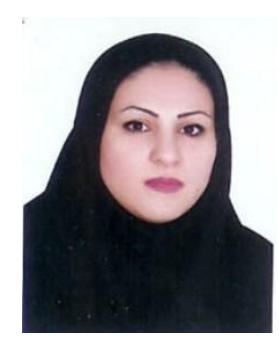

Seyedeh Hoda Sadat Kiyaie is an MA student of TEFL at Tehran Tarbiat Moallem University, Iran. She has a BA degree in English Literature from Azad University of Karaj. Having worked with English language learners of different age groups and with different language proficiency levels since 2003, she is now one of the supervisors of Nur Afshan Language institute in Karaj. She teaches a variety of English language courses in a variety of educational contexts. Her research interests are emotional intelligence and its effects on EFL teachers. 